\title{
The Predictive Role of Neurobiochemical Markers in Multiple Sclerosis
}

\author{
Multiple Sklerozda Nörobiyokimyasal Belirteçlerin Prediktif Rolü
}

\author{
(1) Esra Fırat Oğuz¹, (1) Semra Mungan², (1) Fatma Meriç Yılmaz³, (1) Müjgan Ercan4, (1) Sema Uysal5 \\ 1 University of Health Sciences, Ankara Numune Training and Research Hospital, Clinic of Biochemistry, Ankara, Turkey \\ 2University of Health Sciences, Ankara Numune Training and Research Hospital, Clinic of Neurology, Ankara, Turkey \\ ${ }^{3}$ Ankara Yıldırım Beyazıt University Faculty of Medicine, Department of Biochemistry, Ankara, Turkey \\ ${ }^{4}$ Yozgat Bozok University Faculty of Medicine, Department of Biochemistry, Yozgat, Turkey \\ ${ }^{5}$ Çanakkale Onsekiz Mart University Faculty of Medicine, Department of Biochemistry, Çanakkale, Turkey
}

\begin{abstract}
Introduction: Multiple sclerosis (MS) is the most common, chronic, inflammatory, demyelinating disease of the central nervous system. We aimed to evaluate the levels of some neurobiochemical markers in order to evaluate their predictive role in MS.

Methods: Fifty-one patients with a diagnosis of MS and 37 healthy subjects were included in the study. The patients with MS were diagnosed by a skilled neurologist based on the medical history and physical examination according to revised McDonald criteria. Neuron-specific enolase (NSE) and S100B levels were measured by electrochemiluminescence immunoassay. Glial fibrillary acidic protein (GFAP) and myelin basic protein (MBP) were measured by quantitive sandwich enzyme immunoassay technique with a commercially available ELISA kit.
\end{abstract}

Results: There was a significant difference in NSE levels between the patient and the control groups. No significant difference was determined between the patient and the control groups in terms of S100B, MBP, and GFAP levels. S100B levels were positively correlated with Expanded Disability Status scale scores.

Conclusion: Our findings indicated that NSE levels are significantly lower in MS patients. However, NSE levels should not be used alone at discriminating the disease. Multifactorial evaluation should be done during the diagnosis and follow-up of MS.

Keywords: Multiple sclerosis, GFAP, MBP, NSE, S100B

\section{öZ}

Amaç: Multiple skleroz (MS), merkezi sinir sisteminin en sık görülen, kronik, enflamatuvar ve demiyelinizan hastalığıdır. Bu çalışmada MS'deki prediktif rollerini değerlendirmek için bazı nörobiyokimyasal belirteçlerin seviyelerinin değerlendirilmesi amaçlanmıștır.

Yöntemler: Çalışmaya MS tanısı olan 51 hasta ve 37 sağlıklı birey dahil edilmiştir. MS tanısı, hastalara tıbbi öykü ve revize edilmiş McDonald kriterlerine göre yapılan fizik muayene temelinde uzman bir nörolog tarafından konmuștur. Nöron spesifik enolaz ve S100B düzeyleri elektrokemilüminesan immünoassay ile ölçülmüştür. Glial fibriller asidik protein (GFAP) ve miyelin bazik protein (MBP), ticari olarak temin edilebilen ELISA kiti ile sandviç enzim immün yöntem ile ölçülmüştür.

Bulgular: Hasta ve kontrol grubu arasında NSE düzeylerinde anlamlı bir fark bulunmuștur. Hasta ve kontrol grubu arasında S100B, MBP ve GFAP düzeyleri açısından anlamlı fark saptanmamıştır. S100B seviyeleri Genișletilmiş Özürlülük Durum ölçeği skorları ile pozitif olarak koreleydi.

Sonuç: Bulgularımız NSE düzeylerinin MS hastalarında anlamlı derecede düşük olduğunu göstermiştir. Ancak, NSE düzeyleri hastalığın ayırıcı tanısında tek başına kullanılmamalıdır. MS'nin tanısı ve takibinde multifaktöriyel değerlendirme yapılmalıdır.

Anahtar Kelimeler: Multiple skleroz, GFAP, MBP, NSE, S100B

\section{Introduction}

Multiple sclerosis (MS) is the most common, chronic, inflammatory, demyelinating disease of the central nervous system (CNS) that usually appears in young adults $(1,2)$. Autoimmune response to self-antigens destroys the axons and myelin sheath and causes the formation of characteristic plaques of MS in the white matter of CNS (3). Clinical appearance changes according to the localization of inflammation, demyelination, axonal, and neuronal loss $(2,4)$. Three major forms for MS were described: relapsing-remitting MS (RRMS) that there is a period of recovery after the symptoms, secondary progressive MS (SPMS) that
Address for Correspondence/Yazıșma Adresi: Esra Fırat Oğuz MD, University of Health Sciences, Ankara Numune Training and Research Hospital, Clinic of Biochemistry, Ankara, Turkey

Phone: +90 5379678085 E-mail: dr_esrafirat@hotmail.com ORCID ID: orcid.org/0000-0002-8147-5379

Cite this article as/Atıf: Fırat Oğuz E, Mungan S, Yılmaz FM, Ercan M, Uysal S. The Predictive Role of Neurobiochemical Markers in Multiple Sclerosis. İstanbul Med J 2020; 21(1): 23-7.

(c) Copyright 2020 by the Istanbul Training and Research Hospital/istanbul Medical Journal published by Galenos Publishing House

(C) Telif Hakkı 2020 istanbul Ĕgitim ve Araștırma Hastanesi/Istanbul Tıp Dergisi, Galenos Yayınevi tarafından basıImıștır.
Received/Geliș Tarihi: 17.06.2019 Accepted/Kabul Tarihi: 21.11.2019 
irreversible and progressive destruction occurs after the remission, and primary progressive MS (PPMS) that progressive disability is presented from disease onset. Also, patients usually present initially with clinically isolated syndrome (CIS) defined as a first neurological episode and followed by subacute clinical events, and the symptoms spontaneously remit $(2,5)$.

The destruction of the neuronal tissue of CNS in MS according to the demyelination and axonal degeneration causes the release of proteins such as the calcium-binding protein S100B, neuron-specific enolase (NSE), myelin basic protein (MBP) and glial fibrillary acidic protein (GFAP). S100B is one of the calcium-binding proteins, usually exists in astroglial cells. Elevated levels in both serum and cerebrospinal fluid (CSF) can be detected according to the CNS damage (6). NSE is a glycolytic enzyme, found in neuron cytoplasms and neuroendocrine cells. It is released by damaged neurons, and increased levels are found in both serum and CSF (7). MBP is one of the major proteins of the myelin sheath, and demyelination causes elevated levels of MBP in serum and CSF (8). GFAP exists in the glial cells of the CNS and composes the major protein of the astrocytic cytoskeleton (9).

In the current study, we aimed to evaluate the levels of some neurobiochemical markers in order to evaluate their predictive role in MS.

\section{Methods}

\section{Patients}

Fifty-one patients who admitted to Neurology Department of Ankara Numune Training and Research Hospital with a diagnosis of MS and 37 healthy subjects were included in the study. Informed consent was obtained from all participants included in the study. The patients with MS were diagnosed by a skilled neurologist based on the medical history and physical examination according to revised McDonald criteria (10). The patients were divided into four groups according to their clinical presentation as CIS $(n=4)$, RRMS $(n=36)$, SPMS $(n=8)$ and PPMS $(n=3)$. The disability status was assessed using the Expanded Disability Status scale (EDSS) score (11). The magnetic resonance imaging (MRI) scans of patients were recorded, and the lesions were categorized into four groups according to their location as periventricular, supratentorial, infratentorial, and spinal.

All study procedures were approved by the Ethics Committee of Ankara Numune Training and Research Hospital (decision no: 2012/498).

\section{Blood Samples and Measurement}

Venous blood samples were collected in vacutainer tubes and centrifuged at $1300 \mathrm{~g}$ for 10 minutes. The sera were separated and stored at $-80{ }^{\circ} \mathrm{C}$ until analysis.
NSE and S100B levels were measured by electrochemiluminescence immunoassay technique in Cobas E601 analyzer (Roche Diagnostics, Germany). Detection range of NSE assay was 0.050-370 ng/mL. Detection range of S100B assay was $0.005-39 \mathrm{ng} / \mathrm{mL}$. Intermediate precision of S100B assay was $2.8 \%, 2.0 \%$ and $2.4 \%$ in concentrations of $0.08 \mathrm{ng} / \mathrm{mL}$, $0.24 \mathrm{ng} / \mathrm{mL}$ and $2.13 \mathrm{ng} / \mathrm{mL}$ respectively. Intermediate precision of NSE assay was $4.4 \%, 3.9 \%$ and $4.4 \%$ in concentrations of $2.58 \mathrm{ng} / \mathrm{mL}, 9.32 \mathrm{ng} /$ $\mathrm{mL}$ and $88.0 \mathrm{ng} / \mathrm{mL}$.

GFAP was measured by a quantitive sandwich enzyme immunoassay technique with a commercially available ELISA kit (Uscn Life Science Inc, $\mathrm{PRC}$ ). The detection range of the assay was $0.312-20 \mathrm{ng} / \mathrm{mL}$. Intra and inter-assay precision were $<10 \%$ and $<12 \%$ respectively.

MBP was measured by a commercially available ELISA kit (Uscn Life Science Inc, PRC) using a quantitive sandwich enzyme immunoassay technique. The detection range of the assay was 15.6-1000 pg/mL. Intra and inter-assay precision were $<10 \%$ and $<12 \%$ respectively.

\section{Statistical Analysis}

The findings of this study were analyzed with "Statistical Package for Social Sciences for Windows" (SPSS version 18) software. The conformity of continuous variables to normal distribution was tested with the Kolmogorov-Smirnov test. The descriptive statistics of continuous variables were expressed as mean \pm standard deviation with normal distribution and median (minimum-maximum) with non-normal distribution. The presence of a statistically significant difference between the groups in terms of continuous variables was examined with Student's t-test for parametric and Mann-Whitney $U$ test for non-parametric variables. The presence of a correlation between the groups was searched with Spearman's rho tests. Chi-square test was used for comparison of qualitative data. The area under curve (AUC) was calculated with a receiver operating characteristic (ROC) analysis for statistically significant parameters. $\mathrm{P}<0.05$ was considered the threshold of statistical significance for all tests.

\section{Result}

Fifty-one MS patients (38 males, 13 females) and 37 control subjects (25 males, 12 females) were included in the study. The mean age of the patient group was $36.39 \pm 9.8$ years, and the mean age of the control group was $40.45 \pm 12.37$ years. No significant difference was found in terms of age between the patient and the control groups. There was a significant difference in NSE levels between the patient and the control groups ( $p=0.039$ ). No significant difference was determined between the patient and the control groups in terms of S100B, MBP, and GFAP levels $(p>0.05)$ (Table 1).

Table 1. Comparison of neuron-specific enolase, S100B, glial fibrillary acidic protein and myelin basic protein levels of patient and control groups

\begin{tabular}{|l|l|} 
& Patient group $(\mathbf{n}=51)$ \\
\hline NSE $(\mathrm{ng} / \mathrm{mL})$ & $10.21(1.29-106.60)$ \\
\hline S100B $(\mathrm{ng} / \mathrm{mL})$ & $0.036(0.01-0.21)$ \\
\hline GFAP $(\mathrm{ng} / \mathrm{mL})$ & $4.50 \pm 3.47$ \\
\hline MBP $(\mathrm{pg} / \mathrm{mL})$ & $0.27(0.16-0.50)$ \\
\hline
\end{tabular}

Control group $(\mathbf{n}=37)$

$11.26(7.75-34.62)$

$0.037(0.02-0.23)$

$5.48 \pm 2.81$

$0.27(0.19-0.37)$ p

0.477

0.862

0.162

NSE: neuron-specific enolase, GFAP: glial fibrillary acidic protein, MBP: myelin basic protein 
There was a statistically significant correlation between NSE levels and S100B levels $(r=0.316 ; p=0.003)$. No significant correlation was found between NSE levels and age, GFAP, and MBP levels (Table 2).

The patients were divided into four subgroups according to their clinical phenotype. Seven point eight percent of 51 patients had CIS, 70.6\% had RRMS, $15.6 \%$ had SPMS, and 3.9\% had progressive relapsing MS.

The disability status was evaluated according to EDSS. The patients were divided into two groups according to their EDSS scores. Group 1 with EDSS scores of 1 to 4.5 referred to patients who can walk without any aid and Group 2 with EDSS scores of 5 to 9.5 were defined by the impairment to walking, based on measures of impairment in eight functional systems. S100B levels were positively correlated with EDSS scores $(r=0.282, p=0.045)$.

The lesions of MS patients were categorized into four groups according to their MRI scans and localization. Forty-seven patients had periventricular lesions, 46 patients had supratentorial lesions, 28 had infratentorial lesions, and 24 had spinal lesions. MBP levels were statistically different in patients with supratentorial lesions and without supratentorial lesions $(p=0.007)$.

ROC analysis was performed for serum NSE levels in MS patients (Figure 1). AUC value for NSE was 0.63 (Figure 1). Classifying the accuracy of a diagnostic test was evaluated according to the point system: 0.90-1: excellent, 0.80-0.90: good, 0.70-0.80: fair, 0.60-0.70: poor, 0.50-0.60: fail. NSE was "poor" at distinguishing MS patients from healthy subjects.

Table 2. Correlation between neuron-specific enolase levels and age, S100B, glial fibrillary acidic protein, myelin basic protein

\begin{tabular}{|l|l|l|}
\hline NSE $(\mathbf{n g} / \mathrm{mL})$ & $\mathbf{r}$ & $\mathbf{p}$ \\
\hline Age & -0.003 & 0.978 \\
\hline S100B $(\mathrm{ng} / \mathrm{mL})$ & 0.316 & 0.003 \\
\hline GFAP $(\mathrm{ng} / \mathrm{mL})$ & 0.151 & 0.160 \\
\hline MBP $(\mathrm{pg} / \mathrm{mL})$ & 0.171 & 0.112 \\
\hline
\end{tabular}

NSE: neuron-specific enolase, GFAP: glial fibrillary acidic protein, MBP: myelin basic protein

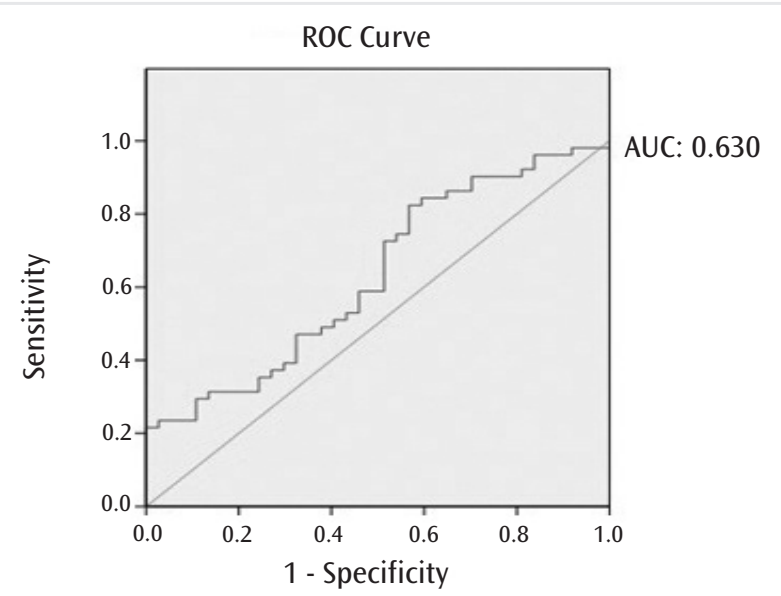

Figure 1. Receiver operating characteristic curve analysis evaluating serum neuron-specific enolase levels in multiple sclerosis patients

ROC: receiver operating characteristic, AUC: area under curve

\section{Discussion}

In the current study, we evaluated the levels of NSE and S100B, GFAP, and MBP levels in patients with MS. Serum NSE levels were statistically significantly lower in the MS group. Serum S100B, GFAP, and MBP levels were not different between the groups. ROC curve analysis showed that serum NSE levels might be a discriminative factor in MS.

In this study, we found similar results with Hein Nee Maier et al. (12) in terms of significantly lower plasma NSE levels of the patients than the healthy control group. In previous studies, NSE levels were higher in patients after traumatic brain injury, stroke, and intracerebral hemorrhage according to the neuronal cell damage (13). We also expected NSE levels to be higher in the patient group as it is known that neuronal loss is one of the reasons for neurological impairment in MS (14). In our study, the patients were in a steady-state of chronic disease, and neuronal loss is usually seen in the early phases of the disease. So, we believe that lower concentrations of NSE levels were associated with a decrease in neuronal loss. Koch et al. (15) also studied NSE levels in MS patients and found lower NSE levels in MS patients, especially in the progressive disease course. They indicated that lower levels of NSE might be related to reduced neuronal activity. Jongen et al. (16) also studied NSE levels in RRMS and SPMS patients and reported that tissue damage was more evident between relapses than in progressive phase, and thus NSE levels were higher in patients with RRMS diagnosis. It is unclear that lower plasma NSE levels in MS patients are associated with a reduced neuronal activity or neuronal loss.

S100B is a marker of glial damage, and increased levels were associated with cerebral damage and/or disruption of the blood-brain barrier (BBB). In previous studies, S100B levels were increased in patients with traumatic brain injury, global hypoxia and cerebral ischemia, stroke (7,17-19). In patients with cerebral ischemia, it was supported that $5100 \mathrm{~B}$ is released during the acute phase of the event (20). The short half-life of $\mathrm{S} 100 \mathrm{~B}$ and this hypothesis can explain the similar concentrations of S100B levels in patients and the control subjects as none of the patients were in the acute phase of the disease. However, we found a positive correlation between S100B levels and the disability status of the patients. The patients with higher disability scores had higher S100B levels.

We found a positive correlation between NSE and S100B levels. A limitation of our study was the fact of the release of S100B and NSE can be originated from non-neuronal tissues: S100B can be released from fat tissue, and NSE can be found in neuroendocrine cells. Also, both of the markers can be released after trauma and inflammation. We tried to minimize these effects by including the patients in clinically steady-state and the control group without any acute or chronic illnesses.

GFAP is one of the major intermediate filament proteins of astrocytes (21). These filaments form astrogliosis and the major dominant protein in chronic MS lesions (22). In previous studies, GFAP levels were shown to be increased in acute damages of brain cells like traumatic brain injury and hydrocephalus $(7,23)$. In studies with MS patients, GFAP levels were found to be significantly elevated in comparison with the control subjects, and GFAP was offered to be a potential biomarker of disease severity of MS $(9,24)$. In contrast with these studies, we did not find 
any difference between patient and control groups in terms of GFAP levels. GFAP is rapidly and remarkably released from brain cells after severe acute brain injury, ischemia, and slowly and mildly elevation of GFAP can be seen in chronic neurological diseases $(25,26)$. GFAP passes through systemic circulation via disrupted BBB. As we studied GFAP levels from the sera of patients, it can be the reason that we did not find elevated levels of GFAP in stable MS patients.

MBP is the major component of the myelin sheath and is essential to the demyelination process. CNS inflammation, BBB breakdown, and the resulting demyelination and neuronal damage and loss are characteristics of MS (27). We did not find any difference between patient and control groups. However, patients with supratentorial lesions had statistically higher MBP levels. In contrast with our study, several studies found elevated MBP levels in patients with MS suggesting a biochemical marker of MS disease activity $(8,28)$. MBP levels increase in CSF following the injury and pass through systemic circulation after the break down of the BBB. The dilution effect can cause lower MBP concentrations according to the larger blood volume. This hypothesis may explain our MBP results.

One of the limitations of our study was that we did not study CSF samples of subjects in terms of biochemical markers. Also, our patients were in the steady-state of the disease; patients in acute or subacute state were not evaluated.

\section{Conclusion}

Evaluating several neurobiochemical marker levels can suggest the state or prognosis of the disease. Our findings indicated that NSE levels were significantly lower in MS patients. However, NSE levels should not be used alone for distinguishing the disease. It should be combined with symptoms, physical and neurological examination, MRI scans, and other markers.

\section{Acknowledgments}

This study was funded by Ankara Numune Training and Researc Hospital Scientific Research Support Budget (634-24/01/2013).

Ethics Committee Approval: All study procedures were approved by the Ethics Committee of Ankara Numune Training and Research Hospital (decision no: 2012/498)

Informed Consent: Informed consent was obtained from all participants included in the study.

Peer-review: Externally peer-reviewed.

Author Contributions: Concept - E.F.O., S.M., F.M.Y., S.U.; Design - E.F.O., S.M., F.M.Y., S.U.; Data Collection and/or Processing - E.F.O., S.M., F.M.Y., M.E., S.U.; Analysis and/or Interpretation - E.F.O., S.M., F.M.Y., M.E.; Literature Search - E.F.O., F.M.Y., M.E., S.U.; Writing Manuscript - E.F.O., F.M.Y.

Conflict of Interest: No conflict of interest was declared by the authors.

Financial Disclosure: This study was funded by Ankara Numune Training and Researc Hospital Scientific Research Support Budget (63424/01/2013).

\section{References}

1. Luessi F, Siffrin V, Zipp F. Neurodegeneration in multiple sclerosis: Novel treatment strategies. Expert Rev Neurother 2012; 12: 1061-76.

2. Nylander A, Hafler DA. Multiple sclerosis. J Clin Invest 2012; 122: 1180-8.

3. Ottervald J, Franzen B, Nilsson K, Andersson LI, Khademi M, Eriksson B, et al. Multiple sclerosis: Identification and clinical evaluation of novel CSF biomarkers. J Proteomics 2010; 73: 1117-32.

4. Matas SL, Glehn F, Fernandes GB, Soares CA. Cerebrospinal fluid analysis in the context of CNS demyelinating diseases. Arq Neuropsiquiatr 2013; 71: 685-8.

5. Thompson AJ, Polman CH, Miller DH, McDonald WI, Brochet B, Filippi M Montalban X, et al. Primary progressive multiple sclerosis. Brain 1997; 120 : 1085-96.

6. Berger RP, Pierce MC, Wisniewski SR, Adelson PD, Clark RS, Ruppel RA, et al. Neuron-specific enolase and S100B in cerebrospinal fluid after severe traumatic brain injury in infants and children. Pediatrics 2002;109:E31.

7. Giacoppo S, Bramanti P, Barresi M, Celi D, Foti Cuzzola V, Palella E, et al. Predictive biomarkers of recovery in traumatic brain injury. Neurocrit Care 2012; 16: 470-7.

8. Ohta M, Ohta K, Ma J, Takeuchi J, Saida T, Nishimura M, et al. Clinical and analytical evaluation of an enzyme immunoassay for myelin basic protein in cerebrospinal fluid. Clin Chem 2000; 46: 1326-30.

9. Axelsson M, Malmestrom C, Nilsson S, Haghighi S, Rosengren L, Lycke J. Glial fibrillary acidic protein: a potential biomarker for progression in multiple sclerosis. J Neurol 2011; 258: 882-8.

10. McDonald WI, Compston A, Edan G, Goodkin D, Hartung HP, Lublin FD, et al. Recommended diagnostic criteria for multiple sclerosis: guidelines from the International Panel on the diagnosis of multiple sclerosis. Ann Neurol 2001; 50: 121-7.

11. Kurtzke JF. Rating neurologic impairment in multiple sclerosis: An expanded disability status scale (EDSS). Neurology 1983; 33: 1444-52.

12. Hein Née Maier K, Kohler A, Diem R, Sättler MB, Demmer I, Lange P, et al. Biological markers for axonal degeneration in CSF and blood of patients with the first event indicative for multiple sclerosis. Neurosci Lett 2008; 436: 72-6.

13. Meynaar IA, Oudemans-van Straaten HM, van der Wetering J, Verlooy P, Slaats $\mathrm{EH}$, et al. Serum neuron-specific enolase predicts outcome in post-anoxic coma: A prospective cohort study. Intensive Care Med 2003; 29: 189-95.

14. Trapp BD, Peterson J, Ransohoff RM, Rudick R, Mork S, Bo L. Axonal transection in the lesions of multiple sclerosis. N Engl J Med 1998; 338: 278-85.

15. Koch M, Mostert J, Heersema D, Teelken A, De Keyser J. Plasma S100beta and NSE levels and progression in multiple sclerosis. J Neurol Sci 2007; 252: 154-8.

16. Jongen PJ, Lamers KJ, Doesburg WH, Lemmens WA, Hommes OR. Cerebrospinal fluid analysis differentiates between relapsing-remitting and secondary progressive multiple sclerosis. J Neurol Neurosurg Psychiatry 1997; 63: 44651.

17. Bouvier D, Fournier M, Dauphin JB, Amat F, Ughetto S, Labbe A, et al. Serum S100B determination in the management of pediatric mild traumatic brain injury. Clin Chem 2012; 58: 1116-22.

18. Martens P, Raabe A, Johnsson P. Serum S-100 and neuron-specific enolase for prediction of regaining consciousness after global cerebral ischemia. Stroke 1998; 29: 2363-6.

19. Brouns R, De Vil B, Cras P, De Surgeloose D, Marien P, De Deyn PP. Neurobiochemical markers of brain damage in cerebrospinal fluid of acute ischemic stroke patients. Clin Chem 2010; 56: 451-8.

20. Jauch EC, Lindsell C, Broderick J, Fagan SC, Tilley BC, Levine SR. Association of serial biochemical markers with acute ischemic stroke: The National Institute 
of Neurological Disorders and Stroke recombinant tissue plasminogen activator Stroke Study. Stroke 2006; 37: 2508-13.

21. Fawcett JW, Asher RA. The glial scar and central nervous system repair. Brain Res Bull 1999; 49: 377-91.

22. Eng LF, Vanderhaeghen JJ, Bignami A, Gerstl B. An acidic protein isolated from fibrous astrocytes. Brain Res 1971; 28: 351-4.

23. Beems T, Simons KS, Van Geel WJ, De Reus HP, Vos PE, Verbeek MM. Serumand CSF-concentrations of brain specific proteins in hydrocephalus. Acta Neurochir (Wien) 2003; 145: 37-43.

24. Takano R, Misu T, Takahashi T, Sato S, Fujihara K, Itoyama Y. Astrocytic damage is far more severe than demyelination in NMO: A clinical CSF biomarker study. Neurology 2010; 75: 208-16.
25. Vissers JL, Mersch ME, Rosmalen CF, van Heumen MJ, van Geel WJ, Lamers $\mathrm{KJ}$, et al. Rapid immunoassay for the determination of glial fibrillary acidic protein (GFAP) in serum. Clin Chim Acta 2006; 366: 336-40.

26. Petzold A, Eikelenboom MJ, Gveric D, Keir G, Chapman M, Lazeron RH, et al. Markers for different glial cell responses in multiple sclerosis: clinical and pathological correlations. Brain 2002; 125: 1462-73.

27. Pouly S, Antel JP, Ladiwala U, Nalbantoglu J, Becher B. Mechanisms of tissue injury in multiple sclerosis: Opportunities for neuroprotective therapy. J Neural Transm Suppl 2000; 193-203.

28. D’Aversa TG, Eugenin EA, Lopez L, Berman JW. Myelin basic protein induces inflammatory mediators from primary human endothelial cells and bloodbrain barrier disruption: Implications for the pathogenesis of multiple sclerosis. Neuropathol Appl Neurobiol 2013; 39: 270-83. 